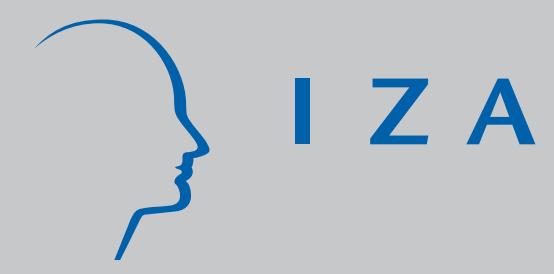

IZA DP No. 910

On-the-J ob Training,

Firing Costs and Employment

Pilar Díaz-Vázquez

Dennis Snower

October 2003 


\title{
On-the-Job Training, Firing Costs and Employment
}

\author{
Pilar Díaz-Vázquez \\ University of Santiago de Compostela \\ Dennis Snower \\ Birkbeck College, University of London, \\ CEPR and IZA Bonn
}

\section{Discussion Paper No. 910 October 2003}

\author{
IZA \\ P.O. Box 7240 \\ D-53072 Bonn \\ Germany \\ Tel.: +49-228-3894-0 \\ Fax: +49-228-3894-210 \\ Email: iza@iza.org
}

This Discussion Paper is issued within the framework of IZA's research area The Future of Labor. Any opinions expressed here are those of the author(s) and not those of the institute. Research disseminated by IZA may include views on policy, but the institute itself takes no institutional policy positions.

The Institute for the Study of Labor (IZA) in Bonn is a local and virtual international research center and a place of communication between science, politics and business. IZA is an independent, nonprofit limited liability company (Gesellschaft mit beschränkter Haftung) supported by Deutsche Post World Net. The center is associated with the University of Bonn and offers a stimulating research environment through its research networks, research support, and visitors and doctoral programs. IZA engages in (i) original and internationally competitive research in all fields of labor economics, (ii) development of policy concepts, and (iii) dissemination of research results and concepts to the interested public. The current research program deals with (1) mobility and flexibility of labor, (2) internationalization of labor markets, (3) welfare state and labor market, (4) labor markets in transition countries, (5) the future of labor, (6) evaluation of labor market policies and projects and (7) general labor economics.

IZA Discussion Papers often represent preliminary work and are circulated to encourage discussion. Citation of such a paper should account for its provisional character. A revised version may be available on the IZA website (www.iza.org) or directly from the author. 
IZA Discussion Paper No. 910

October 2003

\section{ABSTRACT \\ On-the-Job Training, Firing Costs and Employment}

This paper explores the influence of on-the-job training on the employment effect of firing costs. It shows that on-the-job training (generating firm specific skills) causes firing costs to have a contractionary influence on average employment (over the booms and recessions of the business cycle).

JEL Classification: E24, J23, J24, J32, J64

Keywords: average employment, firing costs, on-the-job training

Corresponding author:

Dennis Snower

Department of Economics

Birkbeck College

University of London

7 Gresse Street

London W1P 1PA

UK

Tel.: +442076316408

Fax: +44 2076316416

Email: dsnower@econ.bbk.ac.uk 


\section{Introduction}

The effect of firing costs on employment has been widely studied in the labor economics literature. This paper is concerned with how training influences this effect. We focus on training that arises on the job (as an automatic by-product of working), generating firm-specific skills. We show that as a result of the higher productivity arising from this training, firing costs take on an adverse effect on average employment (over the booms and recessions of the business cycle).

This is an important issue because, as is well known, the supply of skilled workers and skilled jobs has risen dramatically, both in absolute terms and relative to the unskilled workers and jobs, throughout the OECD over the last three decades. The importance of on-the-job training has grown apace. If on-the-job training has an important influence on the way firing costs affect employment, then the role of firing costs in the labor markets of advanced industrialized countries is undergoing change. Specifically, our analysis suggests that skill-biased technological change, applied to firm-specific skills, cause firing costs to have a contractionary influence on employment. As is well known, most OECD countries have experienced pronounced skill-biased technological change over the past three decades, and during this time continental European countries with relatively restrictive job security legislation have, on average, been relatively unsuccessful at creating employment. Our analysis suggests a connection between these two empirical regularities.

The mainstream literature ${ }^{1}$ explains how firing costs discourage both firing and subsequent hiring. Since firms that are engaged in firing must pay firing costs now whereas firms that are engaged in hiring may have to pay firing costs in the future, a standard result is that firing costs may discourage firing more than hiring, thereby raising employment. Other well-known factors pull in the opposite direction. ${ }^{2}$ This paper contributes to this literature by showing that on-the-job training may cause firing costs to have a contractionary influence on average employment. Intuitively, there are two main reasons:

1. Since a rise in firing costs encourages firms to retain their trained workers, the average productivity of the workforce (over booms and recessions) is higher than it would otherwise be. Thus a smaller number of workers, on

\footnotetext{
${ }^{1}$ See, for example, Bentolila and Bertola (1990) and Bertola (1990).

${ }^{2}$ These factors include the following: the rate at which the marginal product of labor declines (Bertola, 1992), firm heterogeneity (Bentolila and Saint-Paul, 1994), the probability of discontinuous drops in macroeconomic activity and the trend rate of productivity growth (Chen, Snower and Zoega, 2002), and wage effects of firing costs (Díaz-Vázquez and Snower, 1996).
} 
average, is required to produce a given cyclical trajectory of output. In this sense, firing costs may reduce average employment.

2. In a downturn (when the firm is engaged in firing), firing costs raise employment in efficiency units; and in an upturn (when the firm is engaged in hiring), firing costs reduce employment in efficiency units. On account of on-the-job training, the workers that are in the firm in the downturn are usually more productive than the workers hired in an upturn. Thus, one efficiency unit of labor in the downturn represents less workers than one efficiency unit of labor in the upturn. As a consequence, the resulting rise in the number of people employed in the recession may be smaller than the resulting fall in the number of people employed in the boom, i.e. firing costs may reduce average employment (over the cycle). ${ }^{3}$

On-the-job training makes the influence of firing costs on employment more contractionary also when we take into account how firing costs affect wages. ${ }^{4}$

To keep the analysis simple, we make some straightforward assumptions: all firms are alike (so that their behavior may be summarized by that of a representative firm), there is no employment growth, the labor demand function is linear, there is no labor hoarding, and the time discount rate is zero. These assumptions are all harmless, since the effects of relaxing them are all well known. The influence of firing costs on employment via firm heterogeneity has been studied by Bentolila and Saint-Paul (1994), among others. The influence of employment growth on the employment effect of firing costs is examined in Chen, Snower, and Zoega (2002). The influence of the curvature of the production function (implying a nonlinear labor demand function) has been covered in Bertola (1992). The influence of the discount factor is already described

\footnotetext{
${ }^{3}$ It is clear that, in practice, the importance of these second channel is likely to depend on the length and depth of the recessions and booms. For instance, if the recession is short and shallow, there may well be labor hoarding. In that case workers are likely to be less productive in recessions than in booms, so that the opposite of the second channel would apply. But if the recession is prolonged and deep, so that there is no labor hoarding - as assumed in our analysis - the second channel becomes operative.

${ }^{4}$ This is so unless a rise in firing costs increases the insider wage so much that there is very little incentive to retain additional workers in a downturn. Under these circumstances, firing costs hardly discourage firing, but they still discourage hiring. In this theoretically possible but implausible case, the presence of on-the-job training can make firing costs less negative for employment. The reason is that when the firm that is engaged in hiring expects the new recruits to acquire on-the-job training in the future, firing costs discourage hiring to a lesser extent.

${ }^{5}$ As is well-known from the insider-outsider literature (see Lindbeck and Snower, 1989), a rise in firing costs increases the insider power in wage determination, which, in turn, affects employment (see Díaz-Vázquez and Snower, 2002, 2003a).
} 
above. $^{6}$ All these influences may be super-imposed on our model, generating the expected modifications of our qualitative results. Thus, for brevity, we omit these influences in our analysis.

The paper is organized as follows. Section 2 presents the underlying model. Section 3 shows, for exogenous wage, the main channels through which the existence of on-the-job training influences the employment effect of firing costs. Section 4 considers endogenous wages. Section 5 concludes.

\section{The Model}

Consider a firm (perfectly competitive in the product market ${ }^{7}$ ) with the following production function: ${ }^{8}$

$$
Z_{t} E_{t}-\frac{b}{2}\left(E_{t}\right)^{2}
$$

where $Z_{t}$ is a stochastic variable indexing business conditions, $E_{t}$ is employment in efficiency units of labor and $b$ is a positive constant. A two-state Markov chain describes the evolution of $Z_{t}$ : in the "boom" $Z_{t}=Z^{+}$, and in the "recession" $Z_{t}=Z^{-}$, where $Z^{+}$and $Z^{-}$are positive constants and $Z^{+}>Z^{-} . P$ is the probability of remaining in previous economic conditions, and thus $(1-P)$ is the probability of a change in economic conditions. The values of $Z^{+}$and $Z^{-}$ determine the employment decision of the firm (for given parameters in the model). ${ }^{9}$ Specifically, we assume that the values of $Z^{+}$and $Z^{-}$are such that in an upturn (when $Z$ moves from a recession $Z^{-}$to a boom $Z^{+}$) the firm hires new workers, in a downturn (when $Z$ moves from a boom $Z^{+}$to a recession $Z^{-}$) the firm fires some workers, and when the current state (the boom or recession) persists, the firm retains its existing workers and hires no new ones.

We assume that $n_{t}^{+}$is the number of new recruits that the firm hires in the upturn, who have no firm-specific skills. During their first period in the firm, the new recruits acquire these firm-specific skills (on-the-job training), ${ }^{10}$ so that at

\footnotetext{
${ }^{6}$ As noted above, with a positive discount factor, an increase in firing costs can raise average employment. The qualitative influence of on-the-job training does not change in this context: the existence of on-the-job training reduces the positive effect of firing costs on employment, and can even make it negative.

${ }^{7}$ This assumption has no implications for the qualitative results of this paper.

${ }^{8}$ We assume a production function with linear marginal product of labor, which allows us to present the argument in the simplest form. In Appendix D we comment on the implications of considering a production function with nonlinear marginal product of labor.

${ }^{9}$ For simplicity, we assume that the values of $Z^{+}$and $Z^{-}$are such as to exclude the trivial and uninteresting special cases, e.g. no hiring in an upturn or no firing in a downturn.

${ }^{10}$ For simplicity, we assume that this on-the-job training is costless. This is not an assump-
} 
the end of the period they are incumbent workers with productivity $A>1$. We assume that in the downturn the firm fires the $n^{+}$workers hired in the previous upturn (i.e. it follows an inverse seniority rule for firing), and retains a number of incumbent workers $N_{t}^{-}$. Thus, in the stationary equilibrium, the firm has $N_{t}^{-}$workers in the recession and $L_{t}^{+}=n_{t}^{+}+N_{t-1}^{-}$workers in the boom. ${ }^{11}$ Since the long-run Markov transition probabilities of a boom and a recession are $\frac{1}{2}$, then average employment (over booms and recessions) is $L=\frac{1}{2}\left(L_{t}^{+}+N_{t}^{-}\right) \cdot{ }^{12}$

We assume that employing new workers involves a hiring cost of $h$ per worker. Each incumbent worker's position is associated with a firing cost of $f$ per worker. The new recruits, however, have their positions associated with firing costs $f_{E}$. We assume that all the wages are predetermined when the employment decisions are made. For clarity, we consider two different scenarios. (1.) In Section 3 we will take the wages as exogenously determined, and also consider that all the workers have their positions associated with firing costs $f$ (i.e. $f_{E}=f$ ). These assumptions allow us to show in a very simple setting the role that the existence of on-the-job training plays in this model. (2.) In Section 4 we extend the analysis for endogenously determined wages, and there we consider that new recruits can be fired costlessly (i.e. $f_{E}=0$ ).

The firm's decision on employment in the hiring scenario is the solution of the following profit maximization: ${ }^{13}$

$$
\underset{n_{t}^{+}}{\operatorname{Max}} Z^{+}\left(n_{t}^{+}+A N_{t-1}^{-}\right)-\frac{b}{2}\left(n_{t}^{+}+A N_{t-1}^{-}\right)^{2}-w_{t}^{+} n_{t}^{+}-W_{t}^{+} N_{t-1}^{-}-h n_{t}^{+}+\Pi_{t+1}^{e}
$$

where $n_{t}^{+}+A N_{t-1}^{-}$is employment in efficiency units of labor in the upturn, $w_{t}^{+}$is the entrants' wage, $W_{t}^{+}$is the incumbent workers' wage, and $\Pi_{t+1}^{e}$ is the expected future profit. Solving (2), the marginal condition for hiring new workers is: ${ }^{14}$

$$
\begin{aligned}
& {\left[Z^{+}-b\left(n_{t}^{+}+A N_{t-1}^{-}\right)\right]-w_{t}^{+}-(1-P) f_{E}} \\
& +P\left\{\frac{1}{1-P}\left[A\left(Z^{+}-b A\left(n_{t}^{+}+N_{t-1}^{-}\right)\right)-W_{t+1}^{+}-(1-P) f\right]\right\}=h
\end{aligned}
$$

tion of substance. Letting it be costly simply introduces a constant into the firm's profit function (since the amount of on-the-job training is constant).

${ }^{11}$ In the upturn, the number of employees in the firm is $L_{t}^{+}=n_{t}^{+}+N_{t-1}^{-}$. If the economy remains in a boom, the firm retains the same number of workers.

${ }^{12}$ The long-run Markov transition probabilities are calculated for $t \rightarrow \infty$. Thus, the level of employment in the first period of the firm (i.e. when the firm is created) becomes irrelevant, and we can approximate average employment with the expression above.

${ }^{13}$ For simplicity, we let the discount rate be zero. Introducing a positive discount factor does not affect our qualitative conclusions.

${ }^{14}$ See Appendix A for the derivation of the marginal conditions in (3) and (7). 
i.e. the expected marginal profit must be equal to the cost of hiring the marginal worker $h$. This marginal condition may be described as follows: (i) in the current period $t$ the new workers' marginal profitability is $\left[Z^{+}-b\left(n_{t}+A N_{t-1}^{-}\right)\right]-w_{t}^{+}$. (ii) With probability $(1-P)$ the firm falls into a recession in period $t+1$ and fires some workers. The marginal new worker is fired and the firm pays the firing cost $-f_{E}$. (iii) With probability $P$ the firm remains in the boom in period $t+1$ and retains all its workers. The present value of the marginal worker's expected profitability is in curly brackets, ${ }^{15}$ where $A\left[Z^{+}-b A\left(n_{t}^{+}+N_{t-1}^{-}\right)\right]$is the marginal product, and $(1-P) f$ is the future expected firing cost.

The expression in (3) determines the total number of people employed in the boom: ${ }^{16}$

$$
L_{t}^{+}=\frac{\left(Z^{+}-w_{t}^{+}-h\right)+\frac{P}{1-P}\left(A Z^{+}-W_{t+1}^{+}\right)-(1-P) f_{E}-\frac{P(1-P)}{1-P} f}{\left(1+\frac{P}{1-P} A^{2}\right) b}-\rho N_{t-1}^{-}
$$

where $-\rho$ equals:

$$
\begin{aligned}
-\rho & =1+\frac{d n_{t}^{+}}{d N_{t-1}^{-}} \\
& =1-\frac{A+\frac{P}{1-P} A^{2}}{1+\frac{P}{1-P} A^{2}}=-\frac{(A-1)(1-P)}{1+P\left(A^{2}-1\right)}
\end{aligned}
$$

Observe that when there is on-the-job training, i.e. $A>1$, total employment in the upturn $L_{t}^{+}$depends inversely on the number of incumbent workers in the firm $N_{t-1}^{-}$. The reason is that incumbent workers are more productive than entrants, and thus one additional skilled worker in the firm displaces more than one new recruit in the next upturn (we can see in (5) that $-1>\frac{\partial n_{t}^{+}}{\partial N_{t-1}^{-}} \geq-A$ ). ${ }^{17}$

The firm's firing decision is the outcome of the following profit maximization problem: ${ }^{18}$

$$
\underset{N_{t}^{-}}{\operatorname{Max}} Z^{-}\left(A N_{t}^{-}\right)-\frac{b}{2}\left(A N_{t}^{-}\right)^{2}-W_{t}^{-} N_{t}^{-}-f\left(L_{1}^{+}-N_{t}^{-}\right)+\Pi_{t+1}^{e}
$$

\footnotetext{
${ }^{15}$ This expression is divided by $(1-P)$ because the marginal profitability at $t+1$ will be the same in any future period as long as the firm remains in a boom (with probability $P$ ).

${ }^{16}$ Note that $n_{t}^{+}+A N_{t-1}^{-}=L_{t}^{+}+(A-1) N_{t-1}^{-}$.

${ }^{17}$ In the absence of on-the-job training, i.e. $A=1$, an additional worker in the recession displaces one new recruit in the next upturn, i.e. $\frac{\partial n_{t}^{+}}{\partial N_{t-1}^{-}}=-1$. This implies that total boom-time employment remains unchanged.

${ }^{18}$ Recall that in a recession all the workers are skilled workers.
} 
where $A N_{t}^{-}$is employment in efficiency units in the recession and $W_{t}^{-}$is the wage. ${ }^{19}$ The marginal condition in the firing scenario is:

$$
\begin{aligned}
& A\left(Z^{-}-b A N_{t}^{-}\right)-W_{t}^{-}-P f+(1-P)\{h \\
& \left.+(A-1)\left[Z^{+}-b\left(n_{t+1}^{+}+A N_{t}^{-}\right)\right]-\left(W_{t+1}^{+}-w_{t+1}^{+}\right)-(1-P)\left(f-f_{E}\right)\right\}=(7)
\end{aligned}
$$

i.e. the profitability of the marginal skilled worker must be equal to the cost of firing him. This marginal condition may be explained as follows: (i) the skilled workers' marginal profitability in the current period is $A\left(Z^{-}-b A N_{t}^{-}\right)-W_{t}^{-}$. (ii) With probability $P$ the recession continues and the expected profit of the marginal worker equals $-f$. (iii) with probability $(1-P)$ economic conditions improve and the firm hires new workers. In this situation, the present value of the skilled workers' expected marginal profitability is in curly brackets: it equals the present value of the unskilled workers' expected marginal profitability, $h,{ }^{20}$ plus the difference between the skilled workers' marginal product in the upturn, $A\left[Z^{+}-b\left(n_{t+1}^{+}+A N_{t}^{-}\right)\right]$, and that of the unskilled workers, $\left[Z^{+}-b\left(n_{t+1}^{+}+A N_{t}^{-}\right)\right]$, the difference in the wage cost in the upturn, $-\left(W_{t+1}^{+}-w_{t+1}^{+}\right)$, and the difference in firing costs next period, $-(1-P)(f-$ $\left.f_{E}\right) \cdot{ }^{21}$

This marginal condition in (7) determines employment in the recession $N_{t}^{-}$ for a given number of new recruits in a future upturn $n_{t+1}^{+}$. Using that $L_{t+1}^{+}=$ $n_{t+1}^{+}+N_{t}^{-}$and solving for $N_{t}^{-}$, we obtain

$$
\begin{aligned}
N_{t}^{-}= & \frac{A Z^{-}-W_{t}^{-}+f-P f}{\left[A^{2}+(1-P)(A-1)^{2}\right] b} \\
& \left.+\frac{(1-P)\left[h+(A-1) Z^{+}-\left(W_{t+1}^{+}-w_{t+1}^{+}\right)-(1-P)\left(f-f_{E}\right)\right]}{\left[A^{2}+(1-P)(A-1)^{2}\right] b}-\sigma L_{t}^{+8}\right)
\end{aligned}
$$

where

$$
-\sigma=\frac{d N_{t}^{-}}{d L_{t+1}^{+}}=-\frac{(1-P)(A-1)}{A^{2}+(1-P)(A-1)^{2}}
$$

\footnotetext{
${ }^{19}$ This is the employment decision in the first downturn the firm encounters. For simplicity we are considering that this occurs when the firm has spent at least two periods in a boom, so that workers have their positions associated with firing costs $f$. In any other downturn, the firm will just keep the same number of workers as in this first downturn.

${ }^{20}$ Recall form the marginal condition in the hiring scenario in (3), that the present value of the unskilled workers' expected marginal profitability equals $h$.

${ }^{21}$ In an upturn, the only difference between the present value of the unskilled workers' expected marginal profitability and the present value of the skilled workers' expected marginal profitability is the marginal product and the wage in the current period, and the expected firing cost next period. This is so because after one period in the firm the unskilled workers become skilled workers, and in their second period in the firm they also have their positions associated with firing costs $f$.
} 
These expressions show that, when $A>1$, the number of employees in the recession $N_{t}^{-}$depends inversely on the level of employment in a future upturn $L_{t+1}^{+}$: the lower is $L_{t+1}^{+}$, the higher is the future expected profitability of the current marginal worker, and thereby the greater is the number of workers in the current recession. ${ }^{22}$

\section{The Employment Effect of Firing Costs}

We first consider that the wages are exogenously determined and that all the workers have their positions associated with firing costs $f$ (i.e. $f=f_{E}$ ). In this context, we examine the employment effect of firing costs, showing how this effect depends on on-the-job training.

\subsection{The Effect in the Absence of on-the-Job Training}

In the absence of on-the-job training, i.e. $A=1$, the employment effect of firing costs in the boom is negative. By equation (4), it equals:

$$
\frac{d L_{t}^{+}}{d f}=-\frac{(1-P)}{b}<0
$$

i.e. a rise in firing costs discourages hiring, since it increases the cost of firing a worker in the future. Conversely, in a recession, the employment effect of firing costs is positive. By equation (8), it equals:

$$
\frac{d N_{t}^{-}}{d f}=\frac{(1-P)}{b}>0
$$

i.e. a rise in firing costs discourages firing, since the firm has to pay the cost today.

Since the effect of firing costs on average employment equals $\frac{d L}{d f}=\frac{1}{2}\left(\frac{d L_{t}^{+}}{d f}+\frac{d N_{t}^{-}}{d f}\right)$, it is clear from equations (10) and (11) that a rise in firing costs has no effect on average employment, since the positive effect in the recession in (11) is equal in magnitude to the negative effect in the boom in (10).

\subsection{The Effect in the Presence of on-the-Job Training}

In the presence of on-the-job training, i.e. $A>1$, by equations (4) and (8), the effect of firing costs on boom-time employment is:

$$
\frac{d L_{t}^{+}}{d f}=\left.\frac{d L_{t}^{+}}{d f}\right|_{\bar{N}^{-}}-\rho \frac{d N_{t-1}^{-}}{d f}
$$

\footnotetext{
${ }^{22}$ This relationship does not exists when $A=1$.
} 
and on recession-time employment is

$$
\frac{d N_{t}^{-}}{d f}=\left.\frac{d N_{t}^{-}}{d f}\right|_{L^{+}}-\sigma \frac{d L_{t+1}^{+}}{d f}
$$

These equations show that the effect of firing costs on short-run employment consists of two effects.

The first effect is the "direct effect" (represented by the first-right hand terms of both (12) and (13)), which is qualitatively the same as the effect described in equations (10) and (11) when $A=1$ : this direct effect in the boom is negative and equals:

$$
\left.\frac{d L_{t}^{+}}{d f}\right|_{\bar{N}^{-}}=-\frac{1-P}{\left[1+P\left(A^{2}-1\right)\right] b}<0
$$

and in the recession it is positive and equals:

$$
\left.\frac{d N_{t}^{-}}{d f}\right|_{L^{+}}=\frac{1-P}{\left[A^{2}+(1-P)(A-1)^{2}\right] b}>0
$$

The second effect is the "indirect effect via employment" (represented by the second right-hand terms of (12) and (13)). To analyze this effect, equation (12) may be rewritten as

$$
\frac{d L_{t}^{+}}{d f}=\frac{1}{1-\rho \sigma}\left(\left.\frac{d L_{t}^{+}}{d f}\right|_{\bar{N}^{-}}-\left.\rho \frac{d N_{t}^{-}}{d f}\right|_{\bar{L}^{+}}\right)
$$

and equation (13) as

$$
\frac{d N_{t}^{-}}{d f}=\frac{1}{1-\rho \sigma}\left(\left.\frac{d N_{t}^{-}}{d f}\right|_{L^{+}}-\left.\sigma \frac{d L_{t}^{+}}{d f}\right|_{\bar{N}^{-}}\right)
$$

This "indirect effect via employment" exists because, in the presence of on-thejob training, the hiring and firing decisions are interdependent. Recall that the number of workers that the firm needs in the boom depends on the number of workers that it has in a recession, as equation (4) shows. As noted, since incumbent workers are more productive than entrants, for each additional incumbent worker in the recession, in the upturn the firm will leave without hiring a number of unskilled new workers greater than one. In other words, an additional skilled worker retained in the recession will be in the firm in the next upturn, and he will displace several (less productive) potential entrants. This means that the positive direct effect of firing costs in the recession translates into a negative "indirect effect via employment" in the boom, as equation (16) shows. 
Similarly, the number of workers that the firm maintains in a recession is conditioned by the number of new workers that it intends to hire in a possible future recovery, as equation (8) shows. Since firing costs reduce the number of new recruits, this gives an incentive for the firm to retain additional workers in a recession. Thus, the negative direct effect of firing costs in the boom translates into a positive "indirect effect via employment" in the recession.

In summary, in the boom both the "direct effect" and the "indirect effect via employment" are negative, i.e. firing costs reduce boom-time employment. In contrast, in the recession both effects are positive, i.e. firing costs increase recession-time employment. In short, the existence of on-the-job training does not change the result that turnover costs stabilize employment over the business cycle.

However, we can show that in the presence of on-the-job training, a rise in firing costs reduces average employment L. By (16) and (17), the effect of firing costs on $L$ equals:

$$
\frac{d L}{d f}=\frac{1}{2(1-\rho \sigma)}\left[\left.\frac{d L_{t}^{+}}{d f}\right|_{\bar{N}^{-}}(1-\sigma)+\left.\frac{d N_{t}^{-}}{d f}\right|_{L^{+}}(1-\rho)\right]
$$

This effect is negative for two reasons.

The first reason is related to the "indirect effect via employment". As noted, the fact that firing costs encourage firms to retain their trained workers in a downturn has the side effect that, for each additional worker that the firm retains, it will leave without recruiting more than one unskilled workers in the upturn. ${ }^{23}$ By the same token, the fact that firing costs discourage the hiring of new unskilled workers has the side effect that the firm will retain more trained workers in the recession. The result is that the average productivity of the workforce is higher than it would otherwise be, and as a consequence, a smaller number of workers on average is required to produce a given cyclical trajectory of output. Thus firing costs reduce average employment. We can see this in equation (18): the magnitude of $\rho$ (i.e. the negative effect that one additional skilled worker has on boom-time employment, in (5)) is greater than $\sigma$ (i.e. the positive effect that one unskilled worker less in the upturn has on recession-time employment, in (9)).

The second reason is that, in the presence of on-the-job training, the positive direct effect in the recession $\left.\frac{d N_{t}^{-}}{d f}\right|_{L^{+}}$becomes smaller in magnitude than the negative direct effect in the boom $\left.\frac{d L_{t}^{+}}{d f}\right|_{\bar{N}^{-}}$, as we can see in equations (14) and

\footnotetext{
${ }^{23}$ Observe that the increase in recession-time employment due to firing costs may even translate into a reduction in average employment if the displacement of new entrants that provokes is sufficiently important, which occurs when $\rho>1$.
} 
(15). ${ }^{24}$ The explanation is the following. The firm is interested in the labor services in efficiency units. In a downturn, firing costs raise employment in efficiency units, and in an upturn, firing costs reduce employment in efficiency units. However, the number of workers that these efficiency units represent is smaller in a recession than in a boom, because the workers that are fired (in a recession) are more productive than the workers that are hired (in a boom). As a consequence, average employment is lower.

In short, in the presence of on-the-job training firing costs reduce average employment because both the "direct effect" and the "indirect effect via employment" of firing costs in the boom are more important than the effects in the recession. ${ }^{25}$

\section{$4 \quad$ Firing costs and wage setting}

In Section 3, the wages are taken as given when analyzing the effects of firing costs on employment. Nevertheless it is well-known from the insider-outsider literature that firing costs also affect insider wages. ${ }^{26}$ To include this fact in the model, we now consider that the skilled workers are the insiders, with firing costs $f$ associated with their positions, and the unskilled workers are the entrants, who can be fired costlessly, i.e. $f_{E}=0$. We assume that the existence of firing costs is what gives power to workers in a wage negotiation with the firm. Thus the entrants have no market power and receive the reservation wage, i.e. the wage that makes them indifferent between employment and unemployment. The insiders, however, belong to a risk-neutral union and bargain over the wage with the firm before the employment decision is made.

The main message of this Section is the following: although a rise in firing costs gives an incentive to retain additional insiders in the recession, when the rise in firing costs also gives much power to the insiders in the wage negotiation, that incentive may become very small (relative to the incentive to reduce hiring in an upturn). Under these theoretically possible circumstances, the result of Section 3 may be different. This is so because in this context firing costs hardly discourage firing, but they still discourage hiring. But this latter effect is weaker the greater is the amount of on-the-job training that the firm expects the new recruits to do in the future. Thus on-the-job training makes the employment

\footnotetext{
${ }^{24}$ Observe in equations (14) and (15) that $A^{2}+(1-P)(A-1)^{2}>1+P\left(A^{2}-1\right)$ and therefore $\left.\frac{d N_{t}^{-}}{d f}\right|_{\bar{L}^{+}}<-\left.\frac{d L_{t}^{+}}{d f}\right|_{\bar{N}^{-}}$.

${ }^{25}$ The analysis of the influence of on-the-job training on the employment effect of hiring costs is identical to the analysis above (observe in equations (4) and (8) that, with no discount factor, firing costs and hiring costs affect employment in an identical way).

${ }^{26}$ See Lindbeck and Snower (1989).
} 
effect of firing costs less contractionary.

\subsection{The union bargaining}

As noted, we assume that the union wage negotiation takes place before the hiring and the firing decisions, i.e. every time economic conditions change. We assume that the union seeks to maximize the utility of the representative insider (the median voter), and that this worker is a "senior" insider who is not fired in the downturn. Thus the union is not worried about the influence that the wage has on employment.

The insider wage is the solution of a Nash bargain. Under disagreement, workers go on strike, which has a cost $\alpha$ per capita for the firm. ${ }^{27}$ We assume that the union can manipulate $\alpha$ and sets it as high as possible, but not as high that the firm replaces the representative insider with a new worker. Thus the representative insider will remain in the firm both under agreement and under disagreement in the negotiation, so we can assume that his future expected profitability is the same in both circumstances, and also his future expected income. Let $w^{0}$ be the current income that the insiders can obtain during a strike, and $\mu$ be the union strength in the negotiation. The insider wage equals: $:^{28}$

$$
W_{t}^{i}=w^{0}+\frac{\mu}{\phi}\left(A Z^{i}-\frac{b}{2} A^{2} N_{t}^{-}-w^{0}+\alpha\right)
$$

where $Z^{i} A-\frac{b}{2} A^{2} N_{t}^{-}$is the product per insider in the current period, ${ }^{29}$ and $\phi=1+(1-\mu) \frac{b}{2} A^{2} \frac{d N_{t}^{-}}{d W_{t}^{i}} \cdot 30$

Since the union sets $\alpha$ subject to the restriction that the representative insider is not replaced by a new worker, then $\alpha$ must not be higher than the cost of firing the insider $f$ plus the cost of hiring the new worker $h$ minus the current profitability of the new worker $\psi$ (which, for simplicity, we take as given). ${ }^{31}$ This restriction is satisfied with equality, since the union seeks to maximize the wage in (19):

$$
\alpha=(f+h)-\psi
$$

\footnotetext{
${ }^{27}$ We assume that the strike is costless to the workers.

${ }^{28}$ See Appendix B for the details of the solution.

${ }^{29}$ In the recession the product per insider is $Z^{-} A-\frac{b}{2} A^{2} N_{t}^{-}$because we consider that the wage is negotiated for the representative worker, who is remaining in the firm. In a boom, the product per insider equals $Z^{+} A-\frac{b}{2} A^{2} N_{t}^{-}$since we assume that the union negotiates the wage on the basis of the product generated by the insiders, before hiring new entrants.

${ }^{30}$ The term $\phi$ does not depend on $f$ and behaves nearly as a constant (see Appendix B).

${ }^{31}$ For simplicity, we assume that the future expected profitability of the current insider and that of the potential entrant are the same (see Appendix B).
} 
From (19) and (20), we can see that a rise in firing costs $f$ have two countervailing effects on the insider wage. On the one hand, it increases the cost that the firm bears under disagreement in the negotiation, and thus increases the negotiated wage. But, on the other hand, the bargained wage depends on the product per worker. The rise in firing costs increases the number of insiders in the firm $N_{t}^{-}$and thus reduces their average product, which reduces the wage. In the next section we assume the first effect dominates, and thus a rise in firing costs increases the insider wage. As we show below, only when a rise in firing costs increases the insider wage a great deal, the influence of on-the-job training described in the previous section may operate in a different way.

\subsection{The employment effect of firing costs when the wage is endogenous}

Let us assume that an unemployed person receives the unemployment benefit $B$ per period, which is a constant. Since we are assuming that entrants receive the reservation wage, i.e. the wage that makes them indifferent between employment and unemployment, then the present value of the entrant's future expected income must be equal to the one of an unemployed person: ${ }^{32}$

$$
w_{t}^{+}+\frac{P}{1-P} W_{t+1}^{+}=\frac{B}{1-P}
$$

i.e. a higher future insider wage is compensated by a lower entrant's wage, so that the present value of the firm's wage payments remains unchanged. ${ }^{33}$ Thus, that entrants receive the reservation wage implies that firing costs have no influence on employment in the upturn via the insider wage. Accordingly, by (4) the employment effect of firing costs in the boom equals:

$$
\frac{d L_{t}^{+}}{d f}=-\frac{P(1-P)}{\left[1+P\left(A^{2}-1\right)\right] b}-\rho \frac{d N_{t-1}^{-}}{d f}
$$

where the first right-hand term is the effect of $f$ on boom-time employment for given $N_{t}^{-},\left.\frac{d L_{t}^{+}}{d f}\right|_{\bar{N}^{-}} \cdot{ }^{34}$

\footnotetext{
${ }^{32}$ Note that $W_{t}^{-}$does not appear in the expression because current entrants are fired in a future recession.

${ }^{33}$ Note that if we substitute (21) into (4), the insider wage disappears from the expression.

${ }^{34}$ This term is similar to (14), although now for firing costs to have a direct influence on the hiring decision, the marginal worker must first become an insider, which occurs with probability $P$.
} 
By contrast, insider wages do have an influence on recession-time employment. By (8) and (21), the effect of firing costs in the recession equals: ${ }^{35}$

$$
\frac{d N_{t}^{-}}{d f}=\frac{P(1-P)-\left(\frac{d W_{t}^{-}}{d f}+\frac{d W_{t+1}^{+}}{d f}\right)}{\left[A^{2}+(1-P)(A-1)^{2}\right] b}-\sigma \frac{d L_{t+1}^{+}}{d f}
$$

where the first right-hand term is $\left.\frac{d N_{t}^{-}}{d f}\right|_{L^{+}}$. As (23) shows, since the marginal worker in the recession is an insider, a rise in firing costs that increases the insider wage (both in the recession and in any possible future boom) will reduce recession-time employment. As a consequence, the number of workers retained in the recession due to the existence of firing costs is lower.

When the increase in the wage due to a rise in firing costs is sufficiently small, i.e. when the term $\frac{d W_{t}^{-}}{d f}+\frac{d W_{t+1}^{+}}{d f}$ in (23) is sufficiently small, then the results of the previous section remain unchanged. However, when this increase is sufficiently large, the results change. Let us consider the extreme case in which $\left.\frac{d N_{t}^{-}}{d f}\right|_{L^{+}}=0$, i.e. although it is more expensive to fire, the insider wage is also higher, and one effect offsets the other. This implies that the only effect of a rise in firing costs is to discourage hiring. As we can see in the expression for $\left.\frac{d L_{t}^{+}}{d f}\right|_{\bar{N}^{-}}$in $(22)$, a rise in firing costs discourages hiring to a lesser extent the greater is the amount of on-the-job training $A$ that the firm expects the new worker to do in the future. Thus, we can conclude that when the influence of firing costs in discouraging firing is very small (relative to the influence of firing costs in discouraging hiring), on-the-job training makes the employment effect of firing costs less contractionary. ${ }^{36}$

\section{Conclusions}

This paper has shown how on-the-job training influences the way in which firing costs affect employment. The reason why on-the-job training plays this role is that it creates a productivity differential between incumbent workers and new recruits, and thereby influences how many new recruits are necessary to replace a given number of incumbents who have been fired in the previous recession. Thus, the firms' hiring and firing decisions become interdependent.

On this account, the number of workers the firm retains in a recession affects the number of workers it needs to hire in a subsequent recovery. Firing costs

\footnotetext{
${ }^{35}$ The wages in the numerator of the expression for $N_{t}^{-}$in $(8)$ are $-W_{t}^{-}-(1-P)\left(W_{t+1}^{+}-\right.$ $\left.w_{t+1}^{+}\right)$. Using $w_{t+1}^{+}$in (21), this expression equals $-W_{t}^{-}-W_{t+1}^{+}+B$.

${ }^{36}$ See Appendix $\mathrm{C}$ for the proof.
} 
encourage firms to retain more workers in a recession. The greater the amount of on-the-job training, the greater the productivity differential between incumbents and new recruits, and thus the fewer new recruits need to be hired in the recovery. In this way, on-the-job training imparts a contractionary influence on the employment repercussions of firing costs.

This influence is strengthened because firing costs increase employment (in efficiency units) in a recession and reduce employment (in efficiency units) in a boom, but the number of workers that these efficiency units represent is smaller in a recession than a boom. On-the-job training generates this channel whereby firing costs reduce average employment over the business cycle. As noted, these results imply that skill-biased technological change, falling on firm-specific skills, makes firing costs harmful for employment. ${ }^{37}$

\section{A Appendix. Derivation of (3) and (7)}

In the boom, the solution of (2) is:

$$
\left[Z^{+}-b\left(n_{t}^{+}+A N_{t-1}^{-}\right)\right]-w_{t}^{+}-(1-P) f_{E}+P \Pi_{t+1}^{++\prime}=h
$$

where $\Pi_{t+1}^{++\prime}$ is the present value of the workers' expected marginal profitability if the firm remains in the boom in period $t+1$, which equals

$$
\Pi_{t+1}^{++\prime}=A\left[Z^{+}-b A\left(n_{t}^{+}+N_{t-1}^{-}\right)\right]-W_{t+1}^{+}+P \Pi_{t+2}^{++\prime}-(1-P) f
$$

Since in the stationary equilibrium $\Pi_{t+1}^{++\prime}=\Pi_{t+2}^{++\prime}$, we have that:

$$
\Pi_{t+1}^{++\prime}=\frac{1}{1-P}\left\{A\left[Z^{+}-b A\left(n_{t}^{+}+N_{t-1}^{-}\right)\right]-W_{t+1}^{+}-(1-P) f\right\}
$$

Substituting equation (26) into (24), the marginal condition in the hiring scenario is the expression in (3).

In the recession, the solution of $(6)$ is:

$$
A\left(Z^{-}-b A N_{t}^{-}\right)-W_{t}^{-}-P f+(1-P) \Pi_{t+1}^{+\prime}=-f
$$

where $\Pi_{t+1}^{+\prime}$ is the present value of the skilled workers' expected marginal profit in a future upturn, which equals:

$$
\Pi_{t+1}^{+\prime}=A\left[Z^{+}-b\left(n_{t+1}^{+}+A N_{t}^{-}\right)\right]-W_{t+1}^{+}-(1-P) f+P \Pi_{t+2}^{++\prime}
$$

\footnotetext{
${ }^{37}$ As explained in the paper, when firing costs discourages firing very little (relative to the magnitude in which it discourages hiring) because a rise in firing costs increases the insider wage a great deal, the presence of on-the-job training can make the employment effect of firing costs less contractionary.
} 
Using equation (24), we can rewrite equation (28) as:

$\Pi_{t+1}^{+\prime}=h+(A-1)\left[Z^{+}-b\left(n_{t+1}+A N_{t}^{-}\right)\right]-\left(W_{t+1}^{+}-w_{t+1}^{+}\right)-(1-P)\left(f-f_{E}\right)$

Substituting (29) into (27), we obtain the marginal condition for firing in (7).

\section{B Appendix. The Nash bargaining}

The Nash bargain is:

$\underset{W_{t}^{i}}{\operatorname{Max}} \Omega=\left[W_{t}^{i}+\theta^{e i}-\left(w^{0}+\theta^{e i}\right)\right]^{\mu}\left[Z^{i} A-\frac{b}{2} A^{2} N_{t}^{-}-W_{t}^{i}+\vartheta^{e i}-\left(-\alpha+\vartheta^{e i}\right)\right]^{1-\mu}$

where $i=+,-$. Under agreement, the worker's utility is $W_{t}^{i}+\theta^{e i}$, where $\theta^{e i}$ is expected utility in the future, and the firm's profit is $Z^{i} A-\frac{b}{2} A^{2} N_{t}^{-}-W_{t}^{i}+\vartheta^{e i}$, where $\vartheta^{e i}$ is the future expected average profit. Under disagreement workers go on strike, and the worker's utility is $w^{0}+\theta^{e i}$, and the firm's expected profit is $-\alpha+\vartheta^{e i}$. Note that $\theta^{e i}$ is identical under agreement and disagreement, and the same happens to $\vartheta^{e i}$, since we assume that the union sets $\alpha$ to avoid the workers being fired during the strike and replaced by new workers. Thus $\alpha$ satisfies the condition $-\alpha+\vartheta^{e i}=-(f+h)+\psi+\vartheta^{e i}$ (we assume that $\vartheta^{e i}$ is identical for the potential entrants and the current insiders). The expression for the wage $W_{t}^{i}$ is the solution of (30), which is in equation (19). The term $\phi=1+(1-\mu) \frac{b}{2} A^{2} \frac{d N_{t}^{-}}{d W_{t}^{i}}$ in (19) appears because, since the wage negotiation occurs before the employment decision, the union must take into account that a rise in the insider wage reduces employment in the recession. This, in turn, increases the revenue per capita, which will further increase the wage. We can show that this term $\phi$ behaves nearly as a constant: (1.) In the case of the insider wage in the boom $W_{t}^{+}$, the term $\frac{\partial N_{t}^{-}}{\partial W_{t}^{+}}$equals zero, since when $W_{t}^{+}$is being negotiated, employment $N_{t}^{-}$is already given. Thus in that case $\phi=1$. (2.) In the recession, we show in Figure A1 that $\phi$ behaves nearly as a constant ( $\phi$ is in the vertical axis, $A$ is in the x-axis and $P$ is in the $\mathrm{y}$-axis). (The expression for $\frac{d N_{t}^{-}}{d W_{t}^{-}}=\frac{-1}{(1-\rho \sigma)\left[A^{2}+(1-P)(A-1)^{2}\right] b}$ is obtained from (8) and (4)). 


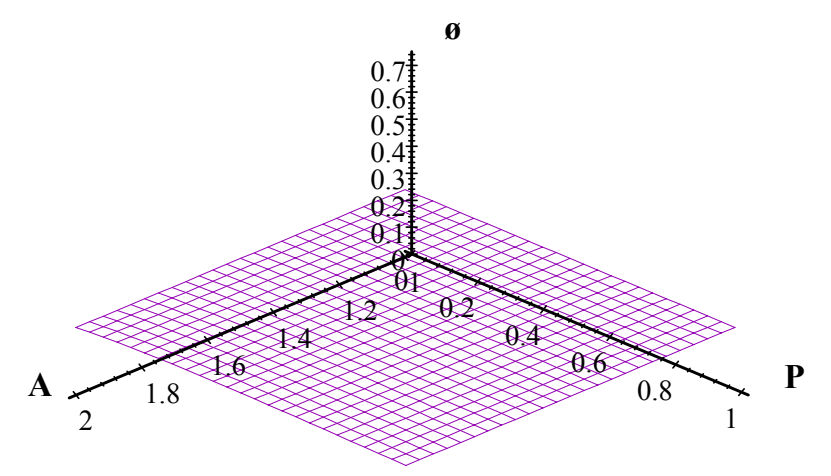

Figure A1

\section{Appendix. Endogenous wage}

The effect of firing costs on the wage in (19) equals: ${ }^{38}$

$$
\frac{d W_{t}^{i}}{d f}=\mu\left(1-\frac{b}{2} A^{2} \frac{d N_{t}^{-}}{d f}\right)
$$

We substitute this expression into (23), and obtain:

$$
\frac{d N_{t}^{-}}{d f}=\frac{P(1-P)-2 \mu}{\left[A^{2}(1-\mu)+(1-P)(A-1)^{2}\right] b}-\widehat{\sigma} \frac{d L_{t+1}^{+}}{d f}
$$

where $\widehat{\sigma}$ equals:

$$
\widehat{\sigma}=\frac{(1-P)(A-1)}{A^{2}(1-\mu)+(1-P)(A-1)^{2}}
$$

Using (22) and (32), we can show how $A$ influences $\frac{d L}{d f}$ when the wages are endogenous. First, we show that the influence of $A$ on the "indirect effect via employment" is qualitatively the same as in Section 3. In that section we showed that, when $A>1$, it holds that $\rho>\sigma$. In the present context, it also holds that $\rho>\widehat{\sigma}$ when $A>\frac{2(1-P)}{2(1-P)-\mu}$. That is, for given $\mu$, when $A$ is sufficiently

\footnotetext{
${ }^{38}$ For simplicity we ignore the term $\phi$, which has no consequences for the qualitative results.
} 
large, a rise in firing costs increases the average productivity of the workforce, and, as a consequence average employment is lower. ${ }^{39}$

Second, let $D e=\left.\frac{d N_{t}^{-}}{d f}\right|_{\bar{L}^{+}}+\left.\frac{d L_{t}^{+}}{d f}\right|_{\bar{N}^{-}}$be the direct effect of firing costs on average employment, where $\left.\frac{d N_{t}^{-}}{d f}\right|_{L^{+}}$is the first right-hand term of (32) and $\left.\frac{d L_{t}^{+}}{d f}\right|_{\bar{N}^{-}}$is the first right-hand term of (22):

$D e=\left.\frac{d N_{t}^{-}}{d f}\right|_{L^{+}}+\left.\frac{d L_{t}^{+}}{d f}\right|_{\bar{N}^{-}}=\frac{P(1-P)-2 \mu}{\left[A^{2}(1-\mu)+(1-P)(A-1)^{2}\right] b}-\frac{P(1-P)}{\left[1+P\left(A^{2}-1\right)\right] b}$

For exogenous wages, we have shown in the paper that, when $A=1$, it holds that the direct effect of firing costs on average employment is zero, whereas when $A>1$ (i.e. when there exists on-the-job training), it holds that the direct effect of firing costs on average employment is negative. ${ }^{40}$ For endogenous wages and when $A=1$, it happens that for any $\mu>0, D e$ is negative:

$$
(D e)_{A=1}=\frac{P(1-P)-2 \mu}{(1-\mu) b}-\frac{P(1-P)}{b}<0
$$

Recall that $\mu$ is the strength of the workers in the Nash bargaining and thus determines the extent to which a rise in firing costs affects the insider wage. We can show that:

1. When $\mu$ is sufficiently small, the existence of on-the-job training makes $D e$ in (34) more negative. Figure A2 shows this. This Figure plots the behavior of $D e$ in (34) with respect to $A$, for different values of $\mu$. We only consider the values of $\mu$ for which $\left.\frac{d N_{t}^{-}}{d f}\right|_{L^{+}} \geq 0$, and thus $\mu \leq \frac{P(1-P)}{2}$. In this Figure $P=0.5$, which implies that the maximum value that $\mu$ can reach is $\mu=0.125$. This Figure shows that when $\mu=0$ and $\mu=0.025$, the existence of on-the-job training makes $D e$ more negative.

2. When $\mu$ is sufficiently large, i.e. $\mu$ comes closer to the value $\frac{P(1-P)}{2}$, the influence of a rise in firing costs in discouraging firing becomes very small relative to the influence in discouraging hiring. Only under these circumstances (which are theoretically possible but implausible), the existence of on-the-job

\footnotetext{
${ }^{39}$ This is usually the case. However, now it might occur that $\rho<\widehat{\sigma}$ when $A<\frac{2(1-P)}{2(1-P)-\mu}$. The reason is the following. When a sufficiently large part of the efficiency per insider does not go to the firm, i.e. when the insider power in the negotiation is sufficiently large and the insider's efficiency is sufficiently low, then it may occur that for the firm insiders are not in fact more efficient than entrants.

${ }^{40}$ This occurs both when $f=f_{E}$, as shown in (14) and (15), and when $f_{E}=0$, as shown in (22) and (23).
} 
training makes $D e$ less negative. For instance, when $A=1$ and $\mu=0.1$, the direct effect of firing costs on recession-time employment is $\left.\frac{d N_{t}^{-}}{d f}\right|_{L^{+}}=55.556,{ }^{41}$ while this effect on boom-time employment is $\left.\frac{d L_{t}^{+}}{d f}\right|_{\bar{N}^{-}}=-250$. Thus the ratio is $\frac{-\left.\frac{d L_{t}^{+}}{d f}\right|_{\bar{N}^{-}}}{\left.\frac{d N_{t}^{-}}{d f}\right|_{\bar{L}^{+}}}=4.5$. In this case, Figure A2 shows that the presence of on-thejob training makes $D e$ less negative. Another example is the case in which $\mu=0.05$ and $A=1.5$. For these values of the parameters, $\left.\frac{d N_{t}^{-}}{d f}\right|_{L^{+}}=66.298$ and $\left.\frac{d L_{t}^{+}}{d f}\right|_{\bar{N}^{-}}=-153.85$. Thus, we can see that the number of workers retained in the recession is very low relative to the number of workers that the firm does not hire in the boom due to a rise in firing costs (the ratio is $\frac{-\left.\frac{d L_{t}^{+}}{d f}\right|_{\bar{N}^{-}}}{\left.\frac{d N_{t}^{-}}{d f}\right|_{\bar{L}^{+}}}=2.32$ ). Figure A2 shows that these are the lowest values of the parameters in the Figure for which the existence of on-the-job training makes $D e$ less negative.

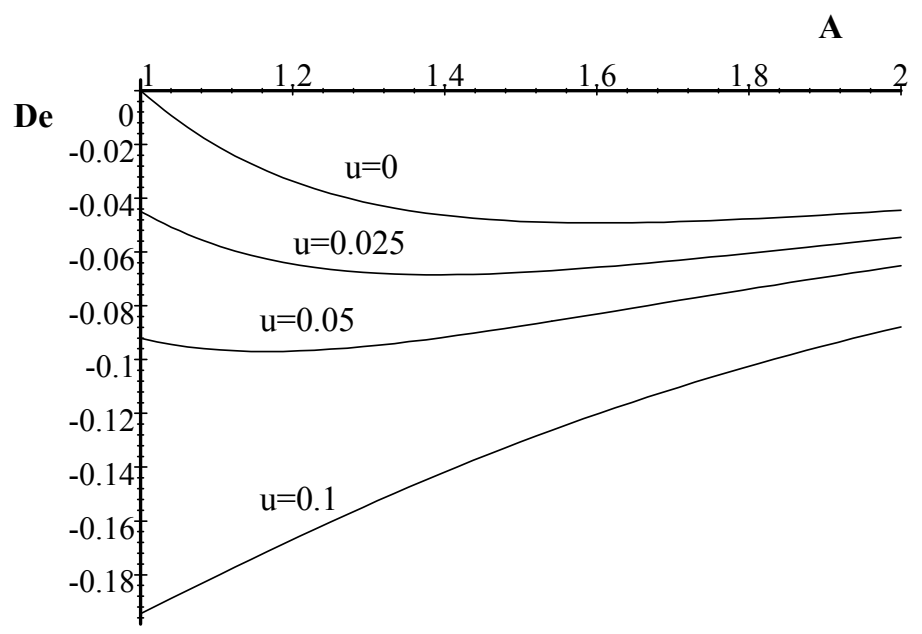

Figure A2

We can do the same exercise for different values of $P$. Figure A3 is the equivalent to Figure A2 but for $P=0.3$, and Figure A4 is the one for $P=0.8$.

\footnotetext{
${ }^{41}$ We are considering that $b=0.001$.
} 


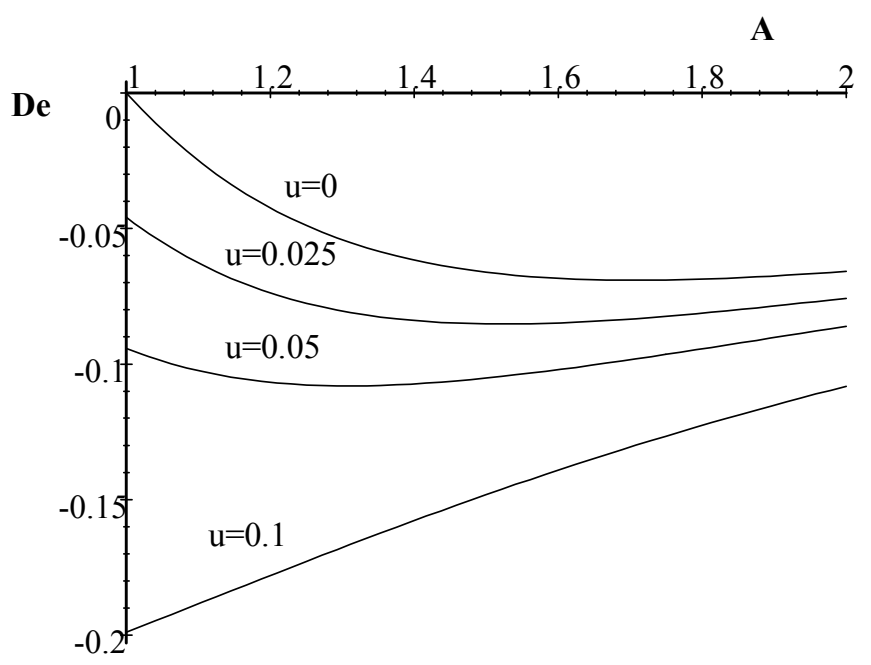

Figure A3

A

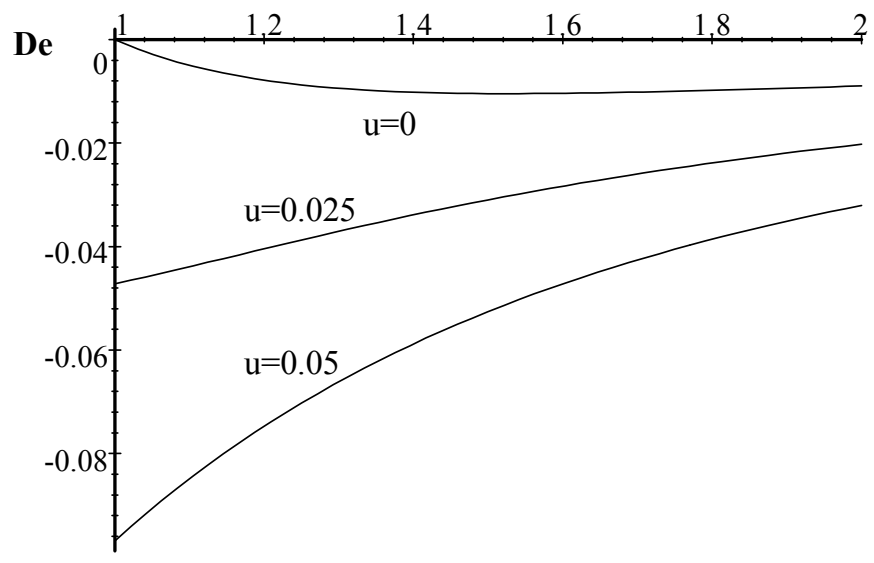

Figure A4

When $P=0.3$, the value of $\mu$ cannot be greater than 0.105 . For instance, when $\mu=0.1$ and $A=1$, it holds that $\left.\frac{d N_{t}^{-}}{d f}\right|_{L^{+}}=11.111$ and $\left.\frac{d L_{t}^{+}}{d f}\right|_{\bar{N}^{-}}=-210$ (the ratio is $\frac{-\left.\frac{d L_{t}^{+}}{d f}\right|_{\bar{N}^{-}}}{\left.\frac{d N_{t}^{-}}{d f}\right|_{L^{+}}}=18.9$ ). In this case, the presence of on-the-job training 
makes De less negative, as we can see in Figure A3. The lowest values of the parameters for which the existence of on-the-job training makes De less negative are $\mu=0.05$ and $A=1.8$. For these values, $\left.\frac{d N_{t}^{-}}{d f}\right|_{L^{+}}=31.197$ and $\left.\frac{d L_{t}^{+}}{d f}\right|_{\bar{N}^{-}}=-125.6$. The ratio is $\frac{-\left.\frac{d L_{t}^{+}}{d f}\right|_{\bar{N}^{-}}}{\left.\frac{d N_{t}^{-}}{d f}\right|_{\bar{L}^{+}}}=4.026$. By the same token, when $P=0.8$, the value of $\mu$ cannot be greater than 0.08 . When $\mu=0.05$ and $A=1$, it holds that $\left.\frac{d N_{t}^{-}}{d f}\right|_{L^{+}}=63.158$ and $\left.\frac{d L_{t}^{+}}{d f}\right|_{\bar{N}^{-}}=-160$. The ratio is $\frac{-\left.\frac{d L_{t}^{+}}{d f}\right|_{\bar{N}^{-}}}{\left.\frac{d N_{t}^{-}}{d f}\right|_{\bar{L}^{+}}}=2.5333$. When $\mu=0.025$ and $A=1.1,\left.\frac{d N_{t}^{-}}{d f}\right|_{\bar{L}^{+}}=93.082$ and $\left.\frac{d L_{t}^{+}}{d f}\right|_{\bar{N}^{-}}=-136.99$. The ratio is $\frac{-\left.\frac{d L_{t}^{+}}{d f}\right|_{\bar{N}^{-}}}{\left.\frac{d N_{t}^{-}}{d f}\right|_{L^{+}}}=1.4717$. Figure A4 shows that for these values of $\mu$, the presence of on-the-job training makes $D e$ less negative.

\section{Appendix. Nonlinear marginal product func- tion}

Let $F^{i}(\cdot)$ be the production function, $i=+,-$. In an upturn, the marginal product equals $F^{+\prime}\left(n_{t}^{+}+A N_{t-1}^{-}\right)$, if the boom persists it equals $A F^{+\prime}\left(A n_{t}^{+}+A N_{t-1}^{-}\right)$, and in a recession it equals $A F^{-1}\left(A N_{t}^{-}\right)$. The effect of $f$ on $L_{t}^{+}$and on $N_{t}^{-}$are in equations (12) and (13), where now $\rho=\frac{(1-P)\left(-F^{+\prime \prime}\left(n_{t}^{+}+A N_{t-1}^{-}\right)\right)(A-1)}{Y}$, $\sigma=\frac{(1-P)\left(-F^{+\prime \prime}\left(n_{t}^{+}+A N_{t-1}^{-}\right)(A-1)\right.}{X},\left.\frac{d L_{t}^{+}}{d f}\right|_{\bar{N}^{-}}=-\frac{1-P}{Y}$ and $\left.\frac{d N_{t}^{-}}{d f}\right|_{L^{+}}=\frac{1-P}{X}$, where $X=-A^{2} F^{-\prime \prime}\left(A N_{t}^{-}\right)-(1-P)(A-1)^{2} F^{+\prime \prime}\left(n_{t+1}^{+}+A N_{t}^{-}\right)$and $Y=-F^{+\prime \prime}\left(n_{t}^{+}+\right.$ $\left.A N_{t-1}^{-}\right)-P\left(A^{2}-1\right) F^{+\prime \prime}\left(A n_{t}^{+}+A N_{t-1}^{-}\right)$.

In Section 3.2 we show that for linear marginal product functions (i.e. $F^{-\prime \prime}(\cdot)$ is a constant), it holds that $X>Y$. This means that the rise in $A$ is reducing more the responsiveness of employment to a change in $f$ in a recession than in a boom. When the marginal product function is nonlinear, i.e. $F^{i \prime \prime}(\cdot)$ depends on employment in efficiency units $E^{i}$, the rise in $A$ also affects $F^{i \prime \prime}(\cdot)$ since it affects $E^{i}$. Let us define $\varepsilon^{i}=\left(-F^{i \prime \prime \prime}\left(E^{i}\right)\right) \frac{E^{i}}{\left(-F^{i \prime \prime}\left(E^{i}\right)\right)},{ }^{42}$ and $\epsilon^{i}=\frac{d E^{i}}{d A} \frac{A}{E^{i}}, i=+,-$. The condition that must be fulfilled for $\frac{d X}{d A}>\frac{d Y}{d A}$ is the following:

$$
\begin{aligned}
& \left(-F^{+\prime \prime}\left(E^{+}\right)\right)\left\{\varepsilon^{+} \epsilon^{+}[A(2 P-1)+2(1-P)]+2[A P-(1-P)(A-1)]\right\} \\
< & A\left(-F^{-\prime \prime}\left(E^{-}\right)\right)\left[2+\varepsilon^{-} \epsilon^{-}\right]
\end{aligned}
$$

\footnotetext{
${ }^{42}$ We assume that the elasticity $\varepsilon^{+}$is the same in any boom.
} 
We make the simplifying assumption that $\epsilon^{i}>0$, i.e. a rise in $A$ increases $E^{i}$. Condition (36) is not fulfilled in the following situations: ${ }^{43}$

a) When $\varepsilon^{i}>0,(36)$ does not hold when $\varepsilon^{+}$is sufficiently greater than $\varepsilon^{-}$. In words, when the marginal product of labor function is concave, condition (36) is not fulfilled when the concavity of the function is sufficiently smaller in a recession than in the boom. Thus a rise in $A$ (that increases $E^{i}$ ) is reducing the responsiveness of employment to a change in $f$ more in a boom than in a recession.

b) When $\varepsilon^{i}<0$, condition (36) does not hold when $\left|\varepsilon^{+}\right|$is sufficiently smaller than $\left|\varepsilon^{-}\right|$. In words, when the marginal product of labor is convex, condition (36) is not fulfilled when the convexity of the function is sufficiently smaller in the boom than in the recession. Thus a rise in $A$ (that increases $E^{i}$ ) is increasing the responsiveness of employment to a change in $f$ more in a recession than in a boom.

\section{References}

[1] Bentolila, S. and G. Bertola, 1990, "Firing Costs and Labor Demand: How Bad is Eurosclerosis?", Review of Economic Studies 57(3), 381-402.

[2] Bentolila, S. and G. Saint-Paul, 1994, "A Model of Labor Demand with Linear Adjustment Costs", Labour Economics 1, 303-326.

[3] Bertola, G., 1990, "Job Security, Employment and Wages", European Economic Review 34, 851-886.

[4] Bertola, G., 1992, "Labor Turnover Costs and Average Labor Demand", Journal of Labor Economics 10, 389-411.

[5] Chen, Y., G. Zoega and D.J. Snower, 2002, "Labor Market Institutions and Macroeconomic Shocks", CEPR Discussion Paper No. 3480.

[6] Díaz-Vázquez, P. and D.J. Snower, 1996, "Employment, Macroeconomic Fluctuations and Job Security", CEPR Discussion Paper 1430.

[7] Díaz-Vázquez, P. and D.J. Snower, 2002, "On-the-Job Training and the Effects of Insider Power", IZA Discussion Paper No. 586.

[8] Díaz-Vázquez, P. and D.J. Snower, 2003, "Can Insider Power Affect Employment?", German Economic Review 4(2), 139-150.

\footnotetext{
${ }^{43}$ When $\epsilon^{i}<0$ the conditions are the opposite.
} 
[9] Lindbeck, A. and D.J. Snower, 1989, The Insider-Outsider Theory of Employment and Unemployment, MIT Press, Cambridge, MA. 


\section{IZA Discussion Papers}

\begin{tabular}{|c|c|c|c|c|}
\hline No. & Author(s) & Title & Area & Date \\
\hline 896 & S. W. Polachek & $\begin{array}{l}\text { What Can We Learn About the Decline in U.S. } \\
\text { Union Membership from International Data? }\end{array}$ & 2 & $10 / 03$ \\
\hline 897 & $\begin{array}{l}\text { M. Brown } \\
\text { A. Falk } \\
\text { E. Fehr }\end{array}$ & $\begin{array}{l}\text { Relational Contracts and the Nature of Market } \\
\text { Interactions }\end{array}$ & 7 & $10 / 03$ \\
\hline 898 & $\begin{array}{l}\text { G. J. van den Berg } \\
\text { A. G. C. van Lomwel } \\
\text { J. C. van Ours }\end{array}$ & $\begin{array}{l}\text { Nonparametric Estimation of a Dependent } \\
\text { Competing Risks Model for Unemployment } \\
\text { Durations }\end{array}$ & 1 & $10 / 03$ \\
\hline 899 & $\begin{array}{l}\text { M. Karanassou } \\
\text { H. Sala } \\
\text { D. J. Snower }\end{array}$ & $\begin{array}{l}\text { Unemployment in the European Union: } \\
\text { Institutions, Prices, and Growth }\end{array}$ & 2 & $10 / 03$ \\
\hline 900 & $\begin{array}{l}\text { M. C. Berger } \\
\text { G. C. Blomquist } \\
\text { K. Sabirianova Peter }\end{array}$ & $\begin{array}{l}\text { Compensating Differentials in Emerging Labor } \\
\text { and Housing Markets: Estimates of Quality of } \\
\text { Life in Russian Cities }\end{array}$ & 4 & $10 / 03$ \\
\hline 901 & $\begin{array}{l}\text { P. F. Orazem } \\
\text { M. Vodopivec }\end{array}$ & $\begin{array}{l}\text { Do Market Pressures Induce Economic } \\
\text { Efficiency: The Case of Slovenian } \\
\text { Manufacturing, 1994-2001 }\end{array}$ & 4 & $10 / 03$ \\
\hline 902 & $\begin{array}{l}\text { P. Frijters } \\
\text { M. A. Shields } \\
\text { S. Wheatley Price }\end{array}$ & $\begin{array}{l}\text { Immigrant Job Search in the UK: Evidence from } \\
\text { Panel Data }\end{array}$ & 1 & $10 / 03$ \\
\hline 903 & $\begin{array}{l}\text { S. Girma } \\
\text { H. Görg }\end{array}$ & $\begin{array}{l}\text { Evaluating the Causal Effects of Foreign } \\
\text { Acquisition on Domestic Skilled and Unskilled } \\
\text { Wages }\end{array}$ & 2 & $10 / 03$ \\
\hline 904 & $\begin{array}{l}\text { S. P. Jenkins } \\
\text { P. Van Kerm }\end{array}$ & $\begin{array}{l}\text { Trends in Income Inequality, Pro-Poor Income } \\
\text { Growth and Income Mobility }\end{array}$ & 1 & $10 / 03$ \\
\hline 905 & $\begin{array}{l}\text { D. Weichselbaumer } \\
\text { R. Winter-Ebmer }\end{array}$ & $\begin{array}{l}\text { Rhetoric in Economic Research: The Case of } \\
\text { Gender Wage Differentials }\end{array}$ & 7 & 10/03 \\
\hline 906 & $\begin{array}{l}\text { D. Weichselbaumer } \\
\text { R. Winter-Ebmer }\end{array}$ & $\begin{array}{l}\text { A Meta-Analysis of the International Gender } \\
\text { Wage Gap }\end{array}$ & 7 & $10 / 03$ \\
\hline 907 & $\begin{array}{l}\text { A. Dupuy } \\
\text { L. Borghans }\end{array}$ & $\begin{array}{l}\text { Supply and Demand, Allocation and Wage } \\
\text { Inequality: An International Comparison }\end{array}$ & 1 & $10 / 03$ \\
\hline 908 & M. Leonardi & Product Demand Shifts and Wage Inequality & 1 & $10 / 03$ \\
\hline 909 & M. Leonardi & $\begin{array}{l}\text { Firm Heterogeneity in Capital/Labor Ratios and } \\
\text { Wage Inequality }\end{array}$ & 1 & $10 / 03$ \\
\hline 910 & $\begin{array}{l}\text { P. Díaz-Vázquez } \\
\text { D. Snower }\end{array}$ & $\begin{array}{l}\text { On-the-Job Training, Firing Costs and } \\
\text { Employment }\end{array}$ & 5 & $10 / 03$ \\
\hline
\end{tabular}

An updated list of IZA Discussion Papers is available on the center's homepage www.iza.org. 